\title{
PENGARUH HARGA DAN KUALITAS PRODUK TERHADAP LOYALITAS MEREK SEPEDA POLYGON STRATTOS DENGAN KEPUASAN KONSUMEN SEBAGAI VARIABEL INTERVENING DI PT INSERA SENA (SURVEI TERHADAP KOMUNITAS POLYGON STRATTOS USER INDONESIA)
}

\author{
Oleh: \\ Martin Yehezkiel Sianipar \\ S1 Manajemen \\ Darwin Lie, Marisi Butarbutar, Julyanthry
}

Abstraksi

Hasil penelitian: 1. Harga, kualitas produk, dan loyalitas merek sepeda Polygon Strattos cukup baik serta kepuasan konsumen masih cukup puas. 2. Terdapat pengaruh harga dan kualitas produk terhadap kepuasan konsumen sepeda Polygon Strattos yang dibuktikan dengan $\hat{Y}_{(\mathrm{Z})}=17,394+0,292 \mathrm{X}_{1}+0,212 \mathrm{X}_{2}$, dan terdapat pengaruh kepuasan konsumen terhadap loyalitas merek yang dibuktikan dengan $\hat{Y}=16,474+0,797 \mathrm{X}_{(\mathrm{Z})} .3$. Terdapat hubungan yang sedang dan positif antara harga dan kualitas produk dengan kepuasan konsumen berdasarkan nilai $\mathrm{r}=0,584$ dengan koefisien determinasi 0,341 . Terdapat hubungan yang sedang dan positif antara kepuasan konsumen dengan loyalitas merek berdasarkan nilai $\mathrm{r}=0,570$ dengan koefisien determinasi 0,325. Hipotesis $\mathrm{H}_{0}$ ditolak, artinya harga dan kualitas produk berpengaruh positif dan signifikan terhadap loyalitas merek sepeda Polygon Strattos melalui kepuasan konsumen sebagai variabel intervening, baik secara simultan maupun parsial.

Adapun saran dari hasil penelitian ini yaitu: 1. Dilihat dari harga, sebaiknya memberikan potongan harga kepada konsumen yang membeli lebih dari 1 (satu) unit. 2. Menyangkut kualitas produk sebaiknya memberikan banyak pilihan warna sepeda. 3. Pada kepuasan konsumen sebaiknya meningkatkan dukungan konsumen terutama terkait informasi sepeda pada website. 4. Pada loyalitas merek sebaiknya memperdulikan kualitas produk.

Kata kunci: Harga, Kualitas Produk, Loyalitas Merek, dan Kepuasan Konsumen.

\section{Abstraction}

The results of this study can be summarized as follows: 1. The price, product quality, and brand loyalty Polygon Strattos on PT Insera Sena quite well and consumers are still quite satisfied. 2. Results of regression analysis is $\hat{\mathrm{Y}}_{\mathrm{Z})}=17,394+0,292 \mathrm{X}_{1}+0,212 \mathrm{X}_{2}$, meaning the price and product quality positively affects consumer satisfaction and simple linear regression result $\hat{\mathrm{Y}}=16,474+0,797 \mathrm{X}_{(\mathrm{z})} .3$. The results of the analysis obtained first correlation $\mathrm{r}=0,584$ means that there is a moderately correlation between price and product quality with consumer satisfaction and the results of the analysis obtained second correlation $\mathrm{r}=0,570$ means that there is a moderately correlation between consumer satisfaction with brand loyalty. The hypothesis $H_{0}$ is rejected, meaning the price and product quality significant positive effect on brand loyalty of Polygon Strattos Bicycle through consumer satisfaction as intervening variable, either simultaneously or partially.

The suggestions from this study are 1. that if viewed from the price, the company should give discount to ritel consumer who buy more one unit, 2. concerning product quality, company should pay attention to the color choice bike, 3. consumer satisfaction should improve consumer support especially related to bike information on the website, and 4. at brand loyalty should care about product quality.

Keywords: Price, Product Quality, Brand Loyalty, and Consumer Satisfaction.

\section{A. PENDAhULUAN}

1. Latar Belakang Masalah

Peningkatan loyalitas merek sangat berkaitan peningkatan kepuasan konsumen. Dalam persaingan antar merek sepeda, merek sepeda global cenderung menjadi pilihan oleh konsumen sepeda di pasar Indonesia. Hal ini nampak dari pangsa pasar sepeda Polygon di Indonesia pada awal tahun 2017 sekitar 20 persen karena persaingan semakin ketat akibat sejumlah merek sepeda global sudah banyak masuk ke pasar Indonesia (Kontan, 2017). Hal tersebut memperkuat riset empiris yang melaporkan bahwa merek-merek global lebih disukai dibandingkan merek-merek lokal, setidaknya di kalangan segmen- segmen konsumen tertentu (Tjiptono, 2005:103). Seiring dengan perkembangan fenomena merek sepeda global tersebut, merek sepeda lokal dituntut mampu meningkatkan loyalitas mereknya agar dapat bersaing dengan merek sepeda global di pasar Indonesia.

PT Insera Sena selaku pemegang merek sepeda Polygon Strattos adalah salah satu perusahaan lokal yang bergerak pada manufaktur sepeda dan perlengkapannya yang berada di Sidoarjo Jawa Timur. Tidak hanya memenuhi pasar domestik, PT Insera Sena juga mulai memasuki pasar ekspor untuk mengembangkan mereknya. Tren bersepeda yang semakin tinggi, serta tingkat persaingan antar 
produsen sepeda yang semakin ketat membuat PT Insera Sena perlu menyesuaikan strategi pemasarannya untuk menjawab tantangan loyalitas merek karena pelanggan yang benar-benar loyal sangat potensial menjadi word-of-mouth advertisers dan loyal pada portofolio produk perusahaan untuk jangka waktu yang lama. Penelitian dalam Hasan (2013) juga menunjukkan bahwa biaya pemasaran yang dibutuhkan untuk mendapatkan pelanggan baru enam kali lebih besar dari biaya untuk mempertahankan pelanggan.

Telah diketahui banyak keuntungan bagi bisnis yang mampu membangun loyalitas mereknya, oleh karena itu usaha untuk meningkatkan loyalitas merek menjadi salah satu tujuan utama PT Insera Sena dalam mempertahankan konsumennya dari merek sepeda global. Loyalitas merek pada penelitian ini ditujukan pada objek produk sepeda Polygon Strattos. Objek yang dimaksud merupakan produk sepeda balap (road-bike) yang diproduksi oleh PT Insera Sena. Loyalitas merek sepeda ini dapat dilihat dari beberapa dimensi, antara lain pelanggan yang suka berpindah (switcher), pelanggan yang membeli karena kebiasaan (habitual buyer), pelanggan yang puas (satisfied buyer), pelanggan yang menyukai merek (liking the brand), dan pelanggan yang komitmen terhadap merek (commited buyer).

Berdasarkan hasil observasi penulis pada Komunitas Polygon Stattos User Indonesia, terdapat fenomena konsumen yang cenderung berpindah merek (switcher) dari Polygon Strattos kepada merek global karena merek global lebih dipersepsikan menawarkan kualitas dan kepuasan yang lebih tinggi kepada konsumen. Kemudian konsumen kurang menyukai merek Polygon Strattos (liking the brand) karena produk belum memberikan kepuasan paling tinggi. Hal tersebut mendukung kajian bahwa loyalitas merek yang tinggi biasanya berawal dari tingkat kepuasan konsumen yang tinggi dan mampu menciptakan ikatan emosional dengan merek tertentu. Berbeda dengan pandangan tersebut, Kotler et. al. (2000:51) menyatakan bahwa sejumlah kajian, yaitu dalam salah satu kategori barang konsumen terdapat $44 \%$ dari mereka yang menyatakan puas akhirnya berganti merek. Oleh karena itu, penulis dalam penelitian ini ingin mengadakan kajian apakah kepuasan konsumen dapat menjadi variabel intervening yang memperantarai hubungan antara pengaruh harga dan kualitas produk terhadap loyalitas merek sepeda Polygon Strattos pada Komunitas Polygon Strattos User Indonesia.

Lingkungan bisnis yang dinamis mendorong PT Insera Sena untuk lebih fokus menanggapi serta meningkatkan kepuasan konsumen untuk menjamin pengembangan dan keberlangsungan bisnis. Adapun keadaan pasar saat ini dimana semakin cerdasnya konsumen, sadar harga, banyak menuntut, kurang memaafkan, dan didekati oleh banyak produk, maka perusahaan juga perlu memperhatikan dimensi kenyamanan prosedur dan dukungan konsumen untuk meningkatkan kepuasan konsumen. Pada dimensi dukungan konsumen, masih terdapat kekurangan dalam hal dukungan konsumen melalui media sosial Polygon Bikes Indonesia yang kurang interaktif dalam merespon konsumen.

Salah satu aspek yang diindikasi memberikan kepuasan konsumen adalah harga melalui dimensi keterjangkauan harga, misalnya harga sepeda Polygon Strattos terjangkau sesuai dengan daya beli konsumen karena produk ini memiliki beberapa seri dengan variasi harga sehingga konsumen dapat memilih sepeda yang sesuai dengan daya belinya. Namun pada dimensi potongan harga, masih terbatasnya pemberian potongan harga pada konsumen yang membeli Polygon Strattos dalam jumlah banyak. Adapun dimensi cara pembayaran, masih terbatasnya fasilitas konsumen untuk membeli secara kredit atau cicilan.

Selain harga, aspek lain yang perlu diperhatikan PT Insera Sena dalam menciptakan kepuasan konsumen adalah kualitas produk. Kualitas produk merupakan kesesuaian produk untuk digunakan dan keberhasilannya menawarkan keistimewaan-keistimewaan yang diinginkan oleh konsumen. Kualitas produk mencakup enam dimensi di dalamnya, yaitu kinerja (performance) berkaitan dengan kualitas fisik Polygon Strattos dalam mendukung kinerja sepeda dalam berbagai rute, keandalan (reliability) yang ditandai dengan diberikannya service gratis untuk setiap pembelian sepeda, fitur (features) yaitu berkaitan dengan tersedianya beberapa fasilitas untuk mencoba sepeda sebagai nilai tambah kepada konsumen.

Adapun dimensi keawetan (durability), ditandai dengan pemberian dukungan garansi rangka sepeda (frameset) selama 5 (lima) tahun, kesesuaian (conformance) berkaitan dengan standar produk berkualitas internasional. Namun pada dimensi estetika (aesthetics) produk ini masih terbatas alternatif pilihan warna yang memungkinkan calon konsumen dapat memilih warna yang sesuai dengan seleranya.

\section{Rumusan Masalah}

a. Bagaimana gambaran harga, kualitas produk, kepuasan konsumen, dan loyalitas merek sepeda Polygon Strattos di PT Insera Sena.

b. Bagaimana pengaruh harga dan kualitas produk terhadap kepuasan konsumen sepeda Polygon Strattos di PT Insera Sena secara simultan.

c. Bagaimana pengaruh harga dan kualitas produk terhadap kepuasan konsumen sepeda Polygon Strattos di PT Insera Sena secara parsial.

d. Bagaimana pengaruh kepuasan konsumen terhadap loyalitas merek sepeda Polygon Strattos di PT Insera Sena.

\section{Tujuan Penelitian}

a. Untuk mengetahui gambaran harga, kualitas produk, kepuasan konsumen dan loyalitas merek sepeda Polygon Strattos di PT Insera Sena.

b. Untuk mengetahui pengaruh harga dan kualitas produk terhadap kepuasan konsumen sepeda Polygon Strattos di PT Insera Sena secara simultan. 
c. Untuk mengetahui pengaruh harga dan kualitas produk terhadap kepuasan konsumen sepeda Polygon Strattos di PT Insera Sena secara parsial.

d. Untuk mengetahui pengaruh kepuasan konsumen terhadap loyalitas merek sepeda Polygon Strattos di PT Insera Sena.

\section{Metode Penelitian}

Objek penelitian adalah Komunitas Polygon Strattos User Indonesia di media sosial Facebook. Populasi adalah seluruh anggota komunitas yang berjumlah 116 orang. Untuk pengambilan sampel pada penelitian ini menggunakan teknik sampling purposive. Menurut Sugiyono (2013:156), sampling purposive adalah teknik penentuan sampel dengan pertimbangan tertentu. Alasan digunakannya sampling purposive untuk melakukan penelitian tentang sepeda Polygon Strattos, maka sampel sumber datanya adalah orang-orang yang telah memiliki dan menggunakan sepeda tersebut, yaitu anggota Komunitas Polygon Strattos User Indonesia. Penyebaran kuesioner penelitian ini terhadap Komunitas Polygon Strattos User Indonesia dilakukan secara online melalui media sosial Facebook. Dari jumlah tersebut diperoleh sampel penelitian yang memenuhi kriteria sebanyak 90 orang.

Desain penelitian adalah Penelitian Kepustakaan (Library Research) dan Penelitian Lapangan (Field Research). Teknik pengumpulan data berupa Kuesioner, Wawancara dan Dokumentasi. Jenis data yang adalah jenis data kualitatif dan data kuantitatif. Hasil data yang diperoleh dari lapangan akan dianalisis secara deskriptif baik bersifat kualitatif dan kuantitatif.

\section{B. LANDASAN TEOR}

\section{Manajemen Pemasaran}

Menurut Kotler dan Kevin (2009:5) manajemen pemasaran (marketing management) adalah seni dan ilmu memilih pasar sasaran dan meraih, mempertahankan, serta menumbuhkan pelanggan dengan menciptakan, menghantarkan, dan mengomunikasikan nilai pelanggan yang unggul. Adapun definisi manajemen pemasaran (marketing management) menurut Doyle (2013:325), adalah praktek dan operasi untuk menjalankan tim atau departemen pemasaran, program pemasaran, penyusunan strategi dan rencana pemasaran. Sedangkan Kotler dan Gary (2008:10), mendefinisikan manajemen pemasaran (marketing management) sebagai seni dan ilmu memilih target pasar dan membangun hubungan yang menguntungkan dengan target pasar itu.

Berdasarkan uraian diatas, dapat disimpulkan bahwa manajemen pemasaran (marketing management) adalah fungsi organisasi yang mengatur penggunaan sumber daya organisasi secara efektif dan efisien untuk mencapai tujuan pemasaran seperti menemukan, menarik, sasaran, memberikan, dan mengkomunikasikan keunggulan nilai bagi

\section{Harga}

Menurut Menurut Hasan (2013:521), konsep harga bagi konsumen merupakan segala bentuk biaya moneter yang dikorbankan oleh konsumen untuk memperoleh, memiliki, memanfaatkan sejumlah kombinasi dari barang beserta pelayanan dari suatu produk. Hasan (2013:521) juga menjelaskan konsep harga bagi perusahaan merupakan cara untuk membedakan penawarannya dari para pesaing. Sedangkan menurut Kotler dan Gary (2008:345), harga adalah sejumlah uang yang ditagihkan atas suatu produk atau jasa, atau jumlah dari nilai yang ditukarkan para pelanggan untuk memperoleh manfaat dari memiliki atau menggunakan suatu produk atau jasa. Lebih lanjut, Kotler dan Gary (2008:345) menyebutkan bahwa harga merupakan satu-satunya elemen dalam bauran pemasaran yang menghasilkan pendapatan; semua elemen lainnya melambangkan biaya.

Berdasarkan beberapa uraian di atas, maka penulis menyimpulkan bahwa harga adalah elemen dari bauran pemasaran yang menyatakan nilai dari suatu produk yang menghasilkan pendapatan bagi suatu organisasi bisnis.

\section{Kualitas Produk}

Menurut Griffin dan Ronald (2006:184), kualitas produk adalah kesesuaian produk untuk digunakan dan keberhasilannya menawarkan keistimewaan-keistimewaan yang diinginkan konsumen. Adapun menurut Kotler dan Kevin (2009:143), definisi kualitas (produk) adalah totalitas fitur dan karakteristik produk atau jasa yang bergantung pada kemampuannya untuk memuaskan kebutuhan yang dinyatakan atau tersirat. Sedangkan menurut Durianto et. al. (2004:38), kualitas produk merupakan penggerak kepuasan pelanggan yang pertama yang memiliki enam elemen, yaitu kinerja (performance), reliabilitas, feature, keawetan (durability), konsistensi, dan desain.

Berdasarkan beberapa pendapat di atas, dengan demikian dapat disimpulkan kualitas produk adalah segala bentuk aktivitas yang dilakukan oleh perusahaan secara langsung guna memenuhi harapan konsumen serta menawarkan elemen-elemen keistimewaan produk yang diinginkan konsumen.

\section{Kepuasan Konsumen}

Menurut Menurut Schnaars dalam Tjiptono (2015:76), pada dasarnya tujuan dari sebuah bisnis adalah untuk menciptakan para pelanggan yang puas. Kepuasan pelanggan dapat diartikan sebagai perbandingan antara harapan atau ekspektasi sebelum pembelian dan persepsi terhadap kinerja setelah pembelian. Adapun Buttle (2007:29), menjelaskan bahwa kepuasan konsumen adalah respons berupa perasaan puas yang timbul karena pengalaman mengonsumsi suatu produk atau layanan, atau sebagian kecil dari pengalaman itu. Sedangkan menurut Kotler et. al. (2000:50), definisi kepuasan konsumen adalah tingkat perasaan seseorang setelah membandingkan kinerja produk 
(atau hasil) yang ia rasakan dengan harapannya. Pelanggan bisa mengalami salah satu dari tingkat kepuasan umum. Jika kinerja di bawah harapan, pelanggan akan tidak puas. Kalau kinerja sesuai dengan harapan, pelanggan akan puas. Sedangkan jika kinerja melampaui harapan, pelanggan akan sangat puas, senang, atau bahagia.

Sementara itu menurut Mowen dan Michael (2002:89), kepuasan konsumen (consumer satisfaction) didefinisikan sebagai keseluruhan sikap yang ditunjukkan konsumen atas barang atau jasa setelah mereka memperoleh dan menggunakannya. Menurut Kotler dan Kevin (2007:177), kepuasan pelanggan adalah perasaan senang atau kecewa pelanggan yang muncul setelah membandingkan kinerja atau hasil produk yang dipikirkan terhadap kinerja atau hasil yang diharapkan. Jika kinerja produk lebih rendah dari harapan pelanggan, pembeli tidak terpuaskan. Jika kinerja sesuai dengan harapan, pembeli terpuaskan. Jika kinerja melebihi yang diharapkan, pembeli lebih senang.

Berdasarkan pendapat para ahli di atas, bisa disimpulkan bahwa definisi kepuasan konsumen adalah respon yang ditunjukkan oleh konsumen dengan membandingkan kinerja aktual produk dengan hasil yang diharapkan. Apabila kinerja lebih rendah dari harapan pelanggan, maka pelanggan akan merasa kecewa karena apa yang diharapkan pelanggan tidak terpuaskan, namun kinerja sesuai dengan harapan, maka pelanggan akan merasa puas.

\section{Loyalitas Merek}

Menurut Griffin (2003:31), loyalitas merek merupakan ukuran yang lebih dapat diandalkan untuk memprediksi pertumbuhan penjualan dan keuangan. Pelanggan yang loyal adalah orang yang melakukan pembelian berulang secara teratur, membeli antarlini produk dan jasa, mereferensikan kepada orang lain, dan menunjukkan kekebalan terhadap tarikan dari pesaing. Sementara itu, Doyle (2013:67) menjelaskan bahwa loyalitas merek didefinisikan sebagai ukuran ketidakmauan konsumen untuk beralih ke produk atau jasa pesaing.

Adapun menurut Hasan (2013:123), definisi loyalitas merek berdasarkan konsep generik, yaitu loyalitas merek merupakan kecenderungan konsumen untuk membeli sebuah merek tertentu dengan tingkat konsistensi yang tinggi. Loyalitas merek juga mencerminkan komitmen psikologis terhadap merek tertentu. Sedangkan Hart dan John (2005:24), mendefinisikan loyalitas merek sebagai dukungan aktif konsumen terhadap keberlangsungan konsumsi produk dengan produk-produk lain yang memiliki merek yang terkenal. Hal ini sejalan dengan definisi menurut Mowen dan Michael (2002:108), bahwa loyalitas merek (brand loyalty) sebagai sejauh mana seorang pelanggan menunjukkan sikap positif terhadap suatu merek, mempunyai komitmen pada merek tertentu, dan berniat untuk terus membelinya di masa depan.

Berdasarkan beberapa pendapat ahli di atas, penulis menyimpulkan loyalitas merek adalah komitmen dan kesetiaan seorang konsumen atau pelanggan yang ditujukan kepada suatu objek dibawah merek tersebut yang sifatnya positif dalam pembelian jangka panjang dan mempunyai keinginan untuk merekomendasikan produk atau jasa kepada orang lain.

\section{PEMBAHASAN \\ 1. Analisis}

\section{a. Deskriptif Kualitatif}

Adapun penetapan kriteria nilai rata-rata jawaban dari responden tersebut dimasukkan kedalam kelas-kelas interval dimana penentuan intervalnya memakai rumus sebagai berikut: Interval Kelas $=\underline{\text { Nilai Tertinggi }- \text { Nilai Terendah }}$

$$
\begin{aligned}
& =\frac{5-1}{5} \\
& =\frac{4}{5} \\
& =0,80
\end{aligned}
$$

Dari rumus diatas dapat diperoleh interval kelas 0,80 sehingga berlaku ketentuan kategori dengan hasil berikut:

Tabel 2

Nilai Interval dan Kategori Jawaban Responden
\begin{tabular}{|c|c|c|}
\hline $\begin{array}{c}\text { Nilai } \\
\text { Interval }\end{array}$ & \multicolumn{2}{|c|}{ Kategori } \\
\hline $1,00-1,80$ & Sangat Tidak Baik & Sangat Tidak Puas \\
\hline $1,81-2,60$ & Tidak Baik & Tidak Puas \\
\hline $2,61-3,40$ & Cukup Baik & Cukup Puas \\
\hline $3,41-4,20$ & Baik & Puas \\
\hline $4,21-5,00$ & Sangat Baik & Sangat Puas \\
\hline
\end{tabular}

Sumber : hasil pengolahan data kuesioner (2017)

\section{1) Gambaran Harga Sepeda Polygon Strattos Pada PT Insera Sena}

Dari hasil analisis, dapat diketahui dimensi keterjangkauan harga untuk indikator keterjangkauan harga sepeda Polygon Strattos telah sesuai dengan daya beli konsumen berada pada tingkat nilai ratarata 3,27 dengan kategori jawaban cukup baik. Hal tersebut disebabkan konsumen menganggap harga sepeda Polygon Strattos yang ditawarkan oleh PT Insera Sena masih cukup tinggi. Untuk indikator kesesuaian harga sepeda Polygon Strattos dengan kualitas produk yang diberikan berada pada tingkat nilai rata-rata 3,49 dengan kategori jawaban baik. Hal ini disebabkan, walaupun PT Insera Sena belum dipersepsikan menawarkan harga yang terjangkau untuk sepeda Polygon Strattos, akan tetapi perusahaan juga berusaha untuk memberikan kualitas produk yang baik kepada setiap konsumennya. Pada indikator kesesuaian harga sepeda Polygon Strattos kompetitif dibandingkan dengan pesaing berada pada tingkat nilai rata-rata 3,21 dengan kategori jawaban cukup baik. Hal tersebut disebabkan PT Insera Sena memberikan harga yang cukup tinggi daripada harga yang ditawarkan oleh produsen sepeda lokal lainnya.

Pada dimensi potongan harga, untuk indikator pemberian potongan harga pada pelanggan yang membeli sepeda Polygon Strattos dalam jumlah banyak berada pada tingkat nilai rata-rata 2,91 
dengan kategori jawaban cukup baik. Hal ini disebabkan PT Insera Sena memberikan potongan harga hanya bagi konsumen korporasi (business to business) yang mengadakan kerja sama pembelian sepeda dalam jumlah banyak, seperti konsumen dari kepolisian, perusahaan BUMN, perguruan tinggi yang membeli sepeda untuk keperluan organisasi atau instutusinya. Untuk indikator pemberian potongan harga pada hari besar berada pada tingkat nilai rata-rata 3,01 dengan kategori jawaban cukup baik. Hal tersebut disebabkan PT Insera Sena hanya memberikan potongan harga pada hari besar seperti pada saat tahun baru, tetapi hal tersebut masih terbatas waktu dan hanya diadakan di beberapa kota saja. Untuk indikator pemberian potongan harga sepeda pada konsumen yang terdaftar sebagai anggota (membership) Rodalink berada pada tingkat nilai rata-rata 3,34 dengan kategori jawaban cukup baik. Hal tersebut disebabkan PT Insera Sena masih terbatas dalam memberikan potongan harga kepada konsumennya, yaitu hanya konsumen yang terdaftar sebagai anggota aktif Rodalink Indonesia.

Selanjutnya, untuk dimensi cara pembayaran pada indikator Polygon Strattos dapat dibayar secara langsung melalui outlet Rodalink bernilai rata-rata 3,88 dengan kategori jawaban baik. Hal ini disebabkan oleh outlet Rodalink sudah memberikan kemudahan dan kenyamanan pembayaran secara tunai bagi konsumennya. Untuk indikator Polygon Strattos dapat dibayar secara transfer bank pada Rodalink berada pada tingkat nilai rata-rata 3,68 dengan kategori jawaban baik. Hal tersebut disebabkan PT Insera Sena sudah memberikan alternatif pembayaran melalui transfer antarbank secara online, sehingga dapat memudahkan konsumen untuk memesan sepeda Polygon Strattos tanpa harus datang langsung ke outlet Rodalink. Lalu, untuk indikator Polygon Strattos dapat dibayar secara kredit pada Rodalink berada pada tingkat nilai rata-rata 3,18 dengan kategori jawaban cukup baik. Hal ini disebabkan layanan pembayaran secara kredit atau cicilan masih terbatas pada beberapa outlet Rodalink saja.

Secara keseluruhan, dapat diketahui bahwa sebagian besar responden berpendapat mengenai harga $\left(\mathrm{X}_{1}\right)$ sepeda Polygon Strattos pada PT Insera Sena berada pada nilai rata-rata 3,33 yang berkategori jawaban cukup baik. Nilai tertinggi berada pada dimensi cara pembayaran, yaitu Polygon Strattos dapat dibayar secara langsung dengan nilai rata-rata 3,88 dengan kategori jawaban baik. Namun masih terdapat indikator yang nilainya masih dibawah rata-rata, yaitu dimensi keterjangkauan harga seperti harga Polygon Strattos terjangkau sesuai dengan daya beli konsumen yang hanya memiliki nilai rata-rata 3,27 dan harga Polygon Strattos kompetitif dibanding pesaing yang hanya memiliki nilai rata-rata 3,21. Kemudian pada dimensi potongan harga seperti pemberian potongan harga pada konsumen yang membeli Polygon Strattos dalam jumlah banyak yang hanya memiliki nilai rata-rata 2,91 dan pemberian potongan harga
Polygon Strattos pada hari-hari besar yang hanya memiliki nilai rata-rata 3,01.

\section{2) Gambaran Kualitas Produk Sepeda Polygon Strattos Pada PT Insera Sena}

Dari hasil analisis, dapat dilihat bahwa dimensi kinerja (performance) dari indikator kualitas frameset Polygon Strattos mendukung kinerja sepeda yang cepat berada pada tingkat nilai rata-rata 3,29 dengan kategori jawaban cukup baik. Hal tersebut disebabkan PT Insera Sena memproduksi sepeda Polygon Strattos dengan bahan aluminium yang cukup tebal. Untuk indikator berat sepeda Polygon Strattos mendukung kinerja sepeda yang cepat berada pada tingkat nilai rata-rata 2,72 dengan kategori jawaban cukup baik. Hal tersebut disebabkan PT Insera Sena memproduksi sepeda ini dengan berat $10,70 \mathrm{~kg}$, sehingga konsumen mempersepsikan sepeda cukup berat dalam kategori road bike. Selanjutnya, untuk indikator geometry Polygon Strattos sesuai dengan postur tubuh orang Indonesia sehingga mendukung kinerja sepeda berada pada tingkat nilai rata-rata 3,20 dengan kategori jawaban cukup baik. Hal ini disebabkan PT Insera Sena mendesain sepeda Polygon Strattos untuk pasar global sehingga mempertimbangkan postur tubuh konsumen secara global juga.

Pada dimensi keandalan (reliability), seperti indikator Polygon Strattos menggunakan komponen berkualitas mendukung keandalan sepeda berada pada tingkat nilai rata-rata 3,11 dengan kategori cukup baik. Dalam hal ini, konsumen menilai Polygon Strattos menggunakan komponen sepeda yang standar di kelasnya. Untuk indikator service gratis tiga 3 (tiga) kali yang diberikan mendukung keandalan sepeda berada pada tingkat nilai rata-rata 3,39 dengan kategori jawaban cukup baik. Hal ini berarti kualitas pengerjaan service gratis dari PT Insera Sena masih terdapat antrian panjang dan lebih memprioritaskan konsumen yang terdaftar sebagai anggota Rodalink. Selanjutnya, untuk indikator Polygon Strattos yang dijual telah dirakit sesuai standar sehingga mendukung keandalan sepeda berada pada tingkat nilai rata-rata 3,50 dengan kategori jawaban baik. Hal ini disebabkan PT Insera Sena selalu memperhatikan standar perakitan sepeda dan selalu menjaga standar tersebut agar konsisten bagi setiap konsumen.

Pada dimensi fitur (feature) dari indikator konsumen mendapat fitur test ride Polygon Strattos di outlet Rodalink milik PT Insera Sena berada pada tingkat nilai rata-rata 2,86 dengan kategori jawaban cukup baik. Hal tersebut disebabkan PT Insera Sena melalui Rodalink belum menjadikan fitur test ride menjadi standar bagi setiap outlet Rodalink. Untuk indikator konsumen mendapat fitur bike fitting sehingga sepeda yang dibeli nyaman dipakai berada pada tingkat nilai rata-rata 2,77 dengan kategori jawaban cukup baik. Hal ini disebabkan PT Insera Sena belum konsisten untuk menyediakan fitur bike fitting untuk semua konsumen sepedanya. Selanjutnya, untuk indikator tersedia ukuran sepeda yang beragam bagi konsumen Polygon Strattos 
berada pada tingkat nilai rata-rata 3,24 dengan kategori jawaban cukup baik. Hal tersebut disebabkan PT Insera Sena masih lambat dalam mendistribusikan Polygon Strattos dalam berbagai ukuran kepada seluruh cabang Rodalink yang dimiliki.

Pada dimensi keawetan (durability) dengan indikator pemberian garansi frameset selama 5 (lima) tahun mendukung keawetan sepeda berada pada tingkat nilai rata 3,71 dengan kategori jawaban baik. Hal tersebut disebabkan PT Insera Sena memproduksi Polygon Strattos dan menjamin frameset sepeda yang digunakan konsumen akan tetap dalam kondisi normal selama pemakaian 5 (lima) tahun. Untuk indikator Polygon Strattos jarang mengalami kerusakan mendukung keawetan sepeda berada tingkat nilai rata-rata 3,18 dengan kategori jawaban cukup baik. Hal tersebut disebabkan PT Insera Sena selalu melakukan quality control terhadap sepeda yang telah selesai diproduksi. Selanjutnya untuk indikator harga jual kembali Polygon Strattos berada pada tingkat nilai rata-rata 3,13 dengan kategori jawaban cukup baik. Hal ini disebabkan harga jual kembali cenderung subyektif tergantung kondisi sepeda dan pemiliknya. Walaupun demikian, harga jual kembali sepeda ini masih kategori baik dan sepeda Polygon Strattos bekas masih diminati oleh konsumen.

Pada dimensi kesesuaian (conformance) dengan indikator Polygon Strattos diproduksi dengan standar internasional berada pada tingkat nilai ratarata 2,92 dengan kategori jawaban cukup baik. Hal tersebut disebabkan pihak PT Insera Sena belum memenuhi standar dari Persatuan Balap Sepeda Internasional atau Union Cycliste Internationale (UCI) untuk sepeda Polygon Strattosnya Selanjutnya, untuk indikator Polygon Strattos diproduksi dengan Standar Nasional Indonesia (SNI) berada pada tingkat nilai rata-rata 3,86 dengan kategori jawaban baik. Hal tersebut disebabkan, pihak PT Insera Sena selalu memproduksi sepeda dengan Standar Nasional Indonesia (SNI). Untuk indikator part pada Polygon Strattos sesuai kebutuhan berada pada tingkat nilai rata-rata 3,40 dengan kategori jawaban baik. Hal tersebut menjelaskan bahwa PT Insera Sena telah melengkapi Polygon Strattos dengan komponen yang sesuai dengan kebutuhan konsumennya.

Pada dimensi estetika (aesthetics) dengan indikator Polygon Strattos mempunyai desain terbaru sehingga mendukung berada pada tingkat nilai ratarata 2,93 dengan kategori jawaban cukup baik. Hal tersebut disebabkan PT Insera Sena memproduksi Polygon Strattos dengan mempertahankan desain sebelumnya dengan sedikit perubahan. Pada indikator Polygon Strattos mempunyai decal (stiker) yang kualitas finishing-nya rapi berada pada tingkat nilai rata-rata 3,14 dengan kategori jawaban cukup baik. Hal tersebut disebabkan PT Insera Sena sudah cukup baik dalam mendesain stiker, namun konsumen masih terdapat sepeda Polygon Strattos dimana catnya masih mudah terkorosi. Selanjutnya untuk indikator Polygon Strattos mempunyai pilihan warna beragam sehingga konsumen dapat memilih berada pada nilai rata-rata 2,58 dengan kategori jawaban tidak baik. Hal tersebut menunjukkan bahwa PT Insera Sena sampai saat ini masih memproduksi Polygon Strattos hanya dengan satu warna untuk setiap serinya.

Secara keseluruhan dapat diketahui bahwa sebagian besar responden berpendapat mengenai kualitas produk $\left(\mathrm{X}_{2}\right)$ pada PT Insera Sena berada pada nilai rata-rata 3,16 yang berkategori jawaban cukup baik. Nilai rata-rata tertinggi berada pada dimensi kesesuaian (conformance), yaitu indikator Polygon Strattos diproduksi dengan Standar Nasional Indonesia (SNI) yang berada pada nilai rata-rata 3,86 dengan kategori jawaban baik. Sedangkan nilai rata-rata terendah berada pada dimensi estetika (aesthetics), yaitu indikator Polygon Strattos mempunyai pilihan warna beragam sehingga konsumen dapat memilih yang hanya memiliki nilai rata-rata 2,58 dengan kategori jawaban tidak baik.

\section{3) Gambaran Kepuasan Konsumen Sepeda} Polygon Strattos Pada PT Insera Sena

Dari hasis analisis, dapat dilihat dimensi kenyamanan prosedur pada indikator tingkat kepuasan atas prosedur pendaftaran sebagai member Rodalink berada pada tingkat nilai rata-rata 3,32 dengan penilaian cukup puas. Hal ini disebabkan PT Insera Sena sudah cukup baik dalam menawarkan keanggotaan (member) Rodalink kepada konsumennya agar mereka dapat menikmati berbagai keuntungan sebagai anggota aktif Rodalink. Untuk indikator tingkat kepuasan konsumen atas kunjungan pada website Rodalink berada pada tingkat nilai ratarata 3,27 dengan penilaian cukup puas. Hal ini disebabkan PT Insera Sena telah menyediakan website yang cukup mumpuni dan memberikan kenyamanan bagi setiap konsumen yang mengaksesnya. Lalu indikator tingkat kepuasan dalam membeli Polygon Strattos pada website Rodalink berada tingkat nilai rata-rata 3,41 dengan penilaian puas. Hal ini disebabkan PT Insera Sena selalu berusaha memberikan kenyamanan dalam prosedur pembelian sepeda secara online kepada konsumennya melalui desain website yang baik dan dapat meminimalkan keluhan dari konsumen.

Pada indikator tingkat kepuasan atas kenyamanan pembelian Polygon Strattos di Rodalink berada pada tingkat nilai rata-rata 3,34 dengan penilaian cukup puas. Hal tersebut disebabkan PT Insera Sena menawarkan kemudahan pembelian dengan alternatif pembayaran sepeda secara tunai maupun transfer bank. Untuk indikator tingkat kepuasan konsumen atas kenyamanan service Polygon Strattos yang dilakukan oleh pihak Rodalink berada pada tingkat nilai rata-rata 3,27 dengan penilaian cukup puas. Hal ini disebabkan PT Insera Sena sudah cukup baik dalam memberikan kenyamanan dalam melayani konsumennya saat mengunjungi dan melakukan service sepeda. Selanjutnya, untuk indikator tingkat kepuasan konsumen atas kenyamanan klaim garansi Polygon Strattos berada pada tingkat nilai rata-rata 3,14 
dengan penilaian cukup puas. Hal ini disebabkan PT Insera Sena harus memberikan kemudahan dan kecepatan bagi konsumen yang melakukan klaim garansi.

Pada dimensi dukungan konsumen untuk indikator tingkat kepuasan atas dukungan konsumen melalui outlet Rodalink berada pada tingkat nilai rata-rata 3,02 dengan penilaian cukup puas. Hal ini disebabkan PT Insera Sena menyediakan outlet Rodalink hanya pada kota-kota besar saja dan belum menjangkau kota-kota kecil yang banyak terdapat konsumen pemilik sepeda Polygon Strattos. Untuk indikator tingkat kepuasan atas dukungan konsumen melalui call center Rodalink berada pada tingkat nilai rata-rata 2,94 dengan penilaian cukup puas. Hal ini disebabkan PT Insera Sena belum memberikan dukungan konsumen melalui call center yang baik karena apabila konsumen menghubungi call center akan mengalami kendala waktu menunggu dan biaya telepon yang tinggi. Selanjutnya untuk indikator tingkat kepuasan atas dukungan konsumen melalui website Rodalink berada pada tingkat nilai rata-rata 3,18 dengan penilaian cukup puas. Hal ini disebabkan PT Insera Sena sudah cukup baik dalam menyajikan tampilan informasi pada website Rodalink, sehingga konsumen cukup terbantu ketika mengakses website tersebut.

Pada indikator tingkat kepuasan atas dukungan konsumen melalui media sosial Polygon Bikes Indonesia berada pada tingkat nilai rata-rata 2,88 dengan penilaian cukup puas. Hal ini disebabkan PT Insera Sena kurang interaktif dalam berkomunikasi di media sosialnya ketika ada pertanyaan maupun keluhan dari konsumen. Selain itu, untuk indikator tingkat kepuasan konsumen atas kecepatan service Polygon Strattos oleh pihak Rodalink berada pada tingkat nilai rata-rata 3,20 dengan penilaian cukup puas. Hal ini disebabkan PT Insera Sena telah memberikan service sepeda yang cepat dan tepat kepada konsumennya. Namun, masih ada beberapa konsumen yang mengeluh karena seringkali terjadi penumpukan antrian di outlet Rodalink yang disebabkan mekanik sepeda yang hanya tersedia satu orang. Selanjutnya, untuk indikator tingkat kepuasan konsumen atas penanganan keluhan yang dilakukan oleh pihak Rodalink berada pada tingkat nilai rata-rata 3,24 dengan penilaian cukup puas. Hal ini disebabkan PT Insera Sena melalui Rodalink berusaha semaksimal mungkin untuk mengatasi keluhan-keluhan konsumen, namun respon dalam memberikan solusi atas keluhan konsumen perlu dipercepat.

Secara keseluruhan dapat diketahui bahwa sebagian besar responden berpendapat mengenai kepuasan konsumen pada PT Insera Sena berada pada nilai rata-rata 3,18 dengan penilaian cukup puas. Nilai rata-rata tertinggi berada pada dimensi kenyamanan prosedur, yaitu indikator tingkat kepuasan dalam membeli Polygon Strattos pada website Rodalink yang memiliki nilai rata-rata 3,41 dengan penilaian puas. Namun masih terdapat kekurangan, yaitu pada indikator tingkat kepuasan atas dukungan konsumen melalui media sosial
Polygon Bikes Indonesia yang hanya memiliki nilai rata-rata 2,88 dengan penilaian cukup puas.

\section{4) Gambaran Loyalitas Merek Sepeda Polygon Strattos Pada PT Insera Sena}

Dari hasil analisis, dapat dilihat bahwa dimensi switcher pada indikator tidak akan berpindah merek dari Polygon Strattos karena faktor harga berada pada tingkat nilai rata-rata 2,96 dengan kategori jawaban cukup baik. Hal ini disebabkan PT Insera Sena belum maksimal dalam memposisikan merek Polygon Strattos sebagai merek sepeda yang terjangkau bagi setiap kalangan. Pada indikator tidak akan berpindah merek dari Polygon Strattos karena faktor kualitas produk berada pada tingkat nilai ratarata 2,92 dengan kategori cukup baik. Hal ini disebabkan PT Insera Sena belum maksimal dalam memposisikan merek Polygon Strattos sebagai merek sepeda yang memiliki kualitas produk yang baik bagi konsumennya. Selanjutnya, untuk indikator tidak akan berpindah merek dari Polygon Strattos karena faktor kepuasan berada pada tingkat nilai 2,92 dengan kategori jawaban cukup baik. Hal ini disebabkan PT Insera Sena belum maksimal dalam memposisikan merek Polygon Strattos sebagai merek sepeda yang memberikan kepuasan kepada konsumennya.

Pada dimensi habitual buyer pada indikator membeli Polygon Strattos hanya karena kebiasaan pribadi berada pada tingkat nilai rata-rata 3,04 dengan kategori jawaban cukup baik. Hal ini disebabkan PT Insera Sena belum menciptakan loyalitas merek yang menjadi preferensi pribadi bagi konsumennya. Lalu untuk indikator membeli Polygon Strattos hanya karena kebiasaan komunitas sepeda berada pada tingkat nilai rata-rata 3,12 dengan kategori jawaban cukup baik. Hal ini disebabkan PT Insera Sena belum menciptakan loyalitas merek yang menjadi preferensi komunitas konsumennya. Selanjutnya untuk indikator membeli Polygon Strattos hanya karena kebiasaan lingkungan berada pada tingkat nilai rata-rata 3,06 dengan kategori jawaban cukup baik. Hal ini disebabkan PT Insera Sena belum menciptakan loyalitas merek yang menjadi preferensi di lingkungan masyarakat.

Pada dimensi satisfied buyer pada indikator menemukan kepuasan dalam menggunakan Polygon Strattos karena faktor harga berada pada tingkat nilai rata-rata 3,37 dengan kategori jawaban cukup baik. Hal ini disebabkan PT Insera Sena sudah menyediakan beberapa seri Polygon Strattos dengan variasi harga, sehingga diharapkan mampu meningkatkan loyalitas merek. Lalu untuk indikator menemukan kepuasan dalam menggunakan Polygon Strattos karena faktor kualitas produk berada pada tingkat nilai rata-rata 3,57 dengan kategori jawaban baik. Hal ini disebabkan PT Insera Sena selalu memperhatikan kualitas produk sepeda Polygon Strattos hingga sampai kepada konsumennya. Selanjutnya untuk indikator menemukan kepuasan dalam menggunakan Polygon Strattos karena faktor merek berada pada tingkat nilai rata-rata 3,03 dengan kategori jawaban cukup baik. Hal ini disebabkan PT 
Insera Sena belum memposisikan merek sepeda Polygon Strattos sebagai sepeda yang memiliki kualitas produk dan memberikan kepuasan kepada konsumennya.

Untuk dimensi liking the brand pada indikator menyukai merek Polygon Strattos karena harga bersaing berada pada tingkat nilai rata-rata 3,34 dengan kategori jawaban cukup baik. Hal ini disebabkan PT Insera Sena menawarkan harga Polygon Strattos sudah cukup bersaing dengan sepeda produsen lokal lainnya. Lalu untuk indikator menyukai merek Polygon Strattos karena kualitas produk tinggi berada pada tingkat nilai rata-rata 3,06 dengan kategori jawaban cukup baik. Hal ini disebabkan masih terdapat konsumen yang menganggap merek sepeda lokal kurang berkualitas dibandingkan dengan merek sepeda global Selanjutnya untuk indikator menyukai merek Polygon Strattos karena produk memberi kepuasan paling tinggi berada pada tingkat nilai rata-rata 2,92 dengan kategori jawaban cukup baik. Hal ini disebabkan PT Insera Sena belum memposisikan merek sepeda Polygon Strattos sebagai merek yang menawarkan kepuasan bagi konsumennya sehingga mampu untuk meningkatkan loyalitas merek sepeda Polygon Strattos.

Pada dimensi commited buyer pada indikator menyarankan merek Polygon Strattos ke orang lain untuk membelinya berada pada tingkat nilai rata-rata 3,36 dengan kategori jawaban cukup baik. Hal ini disebabkan tingkat loyalitas merek sepeda Polygon Strattos pada konsumennya belum maksimal sehingga sebagian konsumen tidak menyarankan merek sepeda ini. Lalu untuk indikator mempromosikan merek sepeda Polygon Strattos ke orang lain untuk membelinya berada pada tingkat nilai rata-rata 3,33 dengan kategori jawaban cukup baik. Hal ini disebabkan PT Insera Sena sudah cukup baik dalam menciptakan loyalitas merek sepeda Polygon Strattos pada konsumennya, sehingga konsumen ikut mempromosikan merek sepeda Polygon Strattos. Selanjutnya untuk pertanyaan tetap memilih merek sepeda Polygon Strattos untuk dibeli dikemudian hari berada pada tingkat nilai rata-rata 2,96 dengan kategori jawaban cukup baik. Hal ini disebabkan PT Insera Sena, walaupun memiliki konsumen yang cukup loyal namun dalam jangka panjang konsumen masih dapat beralih ke merek sepeda lain.

Secara keseluruhan dapat diketahui bahwa sebagian besar responden berpendapat mengenai loyalitas merek (Y) sepeda Polygon Strattos pada PT Insera Sena berada pada nilai rata-rata 3,13 yang berkategori jawaban cukup baik. Nilai rata-rata tertinggi berada pada dimensi satisfied buyer, yaitu indikator menemukan kepuasan dalam menggunakan Polygon Strattos karena faktor kualitas produk yang berada pada nilai rata-rata 3,53 dengan kategori jawaban baik. Sedangkan nilai rata-rata terendah berada pada dimensi switcher, yaitu indikator tidak akan berpindah merek dari Polygon Strattos karena faktor kualitas produk dan indikator tidak akan berpindah merek dari Polygon Strattos karena faktor kepuasan yang berada pada nilai rata-rata 2,92 dengan kategori jawaban cukup baik. Juga pada dimensi liking the brand pada indikator menyukai merek Polygon Strattos karena produk memberi kepuasan paling tinggi dengan nilai rata-rata 2,92 dengan kategori jawaban cukup baik.

\section{b. Deskriptif Kuantitatif \\ 1) Analisis Regresi}

Analisis regresi linear berganda digunakan untuk mengetahui pengaruh variabel bebas $(X)$ terhadap variabel intervening $(Z)$, dan analisis regresi linear sederhana untuk mengetahui pengaruh variabel intervening $(\mathrm{Z})$ terhadap variabel terikat $(\mathrm{Y})$, dimana variabel $\mathrm{X}_{1}$ adalah harga, $\mathrm{X}_{2}$ adalah kualitas produk, $\mathrm{Z}$ adalah kepuasan konsumen, dan $\mathrm{Y}$ adalah loyalitas merek.

a) Pengaruh Harga dan Kualitas Produk Terhadap Kepuasan Konsumen

Tabel 3

Hasil Regresi Linear Berganda

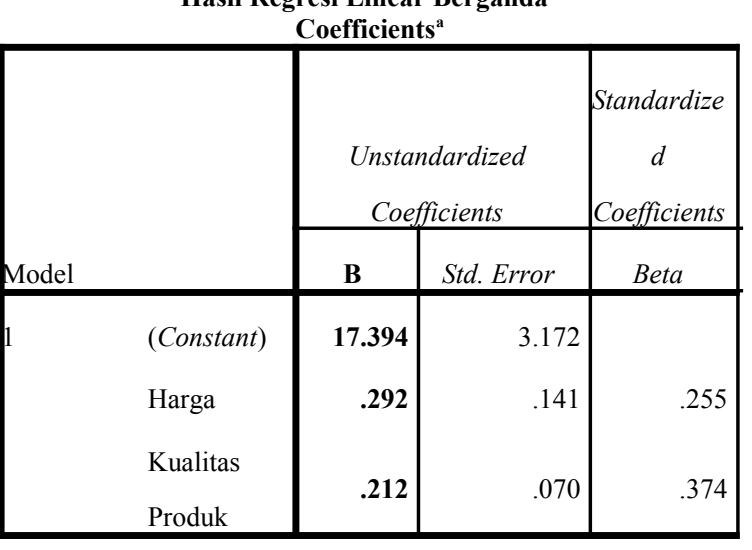

a. Dependent Variable: Kepuasan Konsumen

Sumber: hasil pengolahan data dengan SPSS versi 21 Dari tabel 3 di atas, dapat diperoleh persamaan koefisien regresi, yaitu $\hat{\mathrm{Y}}_{(\mathrm{z})}=17,394+$ $0,292 X_{1}+0,212 X_{2}$, artinya terdapat pengaruh positif antara harga dan kualitas produk terhadap kepuasan konsumen sepeda Polygon Strattos pada PT Insera Sena.

b) Pengaruh Harga Terhadap Kepuasan Konsumen

Tabel 4

Hasil Regresi Linear Sederhana Coefficients $^{\mathrm{a}}$

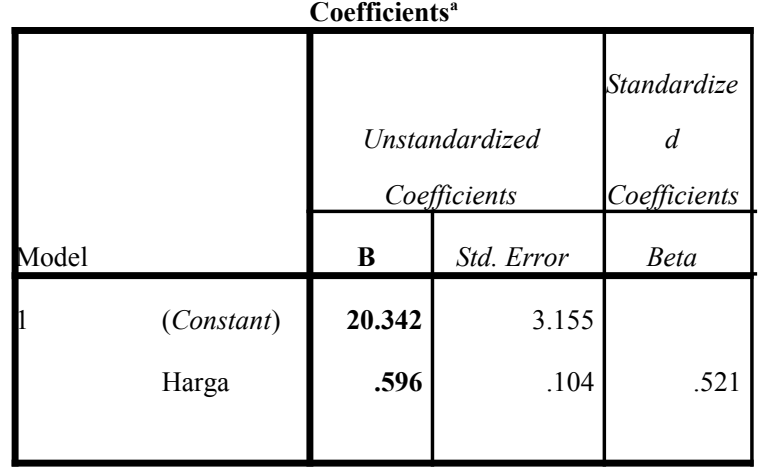


a. Dependent Variable: Kepuasan Konsumen Sumber: hasil pengolahan data dengan SPSS versi 21

Dari tabel 4 di atas, dapat diperoleh persamaan koefisien regresi, yaitu $\hat{\mathrm{Y}}_{(\mathrm{z})}=20,342+$ 0,596X, artinya terdapat pengaruh positif antara harga terhadap kepuasan konsumen sepeda Polygon Strattos pada PT Insera Sena.

c) Pengaruh Kualitas Produk Terhadap Kepuasan Konsumen

Tabel 5

Hasil Regresi Linear Sederhana Coefficients

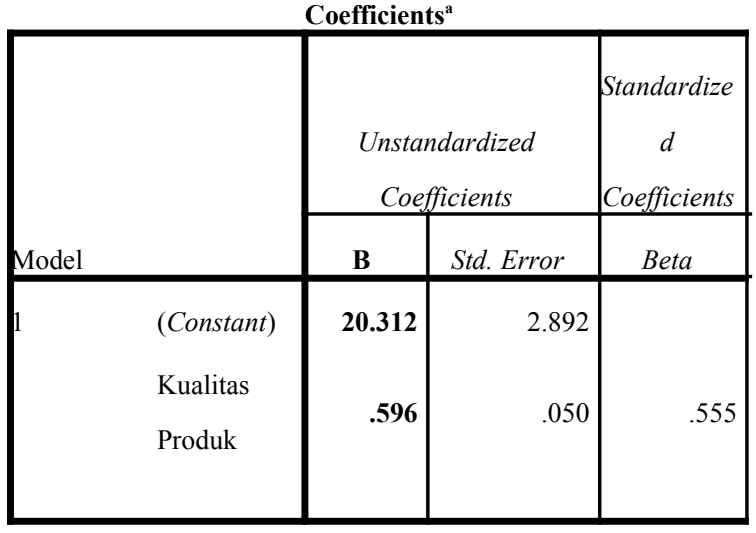

a. Dependent Variable: Kepuasan Konsumen

Sumber: hasil pengolahan data dengan SPSS versi 21

Dari tabel 5 di atas, dapat diperoleh persamaan koefisien regresi, yaitu $\hat{\mathrm{Y}}_{(\mathrm{z})}=20,312+$ $0,315 \mathrm{X}$, artinya terdapat pengaruh positif antara kualitas produk terhadap kepuasan konsumen sepeda Polygon Strattos pada PT Insera Sena.

d) Pengaruh Kepuasan Konsumen Terhadap Loyalitas Merek

Tabel 6

Hasil Regresi Linear Sederhana Coefficients $^{\mathrm{a}}$

\begin{tabular}{|c|c|c|c|}
\hline \multirow[b]{2}{*}{ Model } & \multicolumn{2}{|c|}{$\begin{array}{c}\text { Unstandardized } \\
\text { Coefficients }\end{array}$} & $\begin{array}{c}\text { Standardize } \\
d \\
\text { Coefficients }\end{array}$ \\
\hline & B & Std. Error & Beta \\
\hline (Constant) & 16.474 & 4.723 & \\
\hline Harga & .797 & .123 & .570 \\
\hline
\end{tabular}

a. Dependent Variable: Loyalitas Merek

Sumber: hasil pengolahan data dengan SPSS versi 21

Dari tabel 6 di atas, dapat diperoleh persamaan koefisien regresi, yaitu $\hat{\mathrm{Y}}=16,474+$ $0,797 \mathrm{X}_{(\mathrm{Z})}$, artinya terdapat pengaruh positif antara kepuasan konsumen terhadap loyalitas merek sepeda Polygon Strattos pada PT Insera Sena.
2) Analisis Korelasi dan Koefisien Determinasi

a) Hubungan Harga dan Kualitas Produk dengan Kepuasan Konsumen

Hasil koefisien korelasi dan koefisien determinasi dapat dilihat pada tabel berikut:

Tabel 7

Hasil Koefisien Korelasi dan Koefisien Determinasi

\begin{tabular}{|c|c|c|c|c|}
\hline Model & $\mathbf{R}$ & $\begin{array}{c}\mathbf{R} \\
\text { Square }\end{array}$ & $\begin{array}{c}\text { Adjusted } R \\
\text { Square }\end{array}$ & $\begin{array}{c}\text { Std. Error of the } \\
\text { Estimate }\end{array}$ \\
\hline 1 & $\mathbf{. 5 8 4}^{\mathrm{a}}$ & $\mathbf{. 3 4 1}$ & .326 & 4.139 \\
\hline
\end{tabular}

a. Predictors: (Constant), Harga, Kualitas Produk

b. Dependent Variable: Kepuasan Konsumen Sumber: hasil pengolahan data dengan SPSS versi 21

Berdasarkan tabel 7, telah didapat $\mathrm{r}=0,584$ yang artinya terdapat hubungan yang sedang dan positif antara harga dan kualitas produk dengan kepuasan konsumen sepeda Polygon Strattos pada PT Insera Sena. Selanjutnya diperoleh koefisien determinasi R square 0,341 artinya tinggi rendahnya kepuasan konsumen sebesar 34,1\% dapat dijelaskan oleh variabel harga dan kualitas produk, sedangkan sisanya $65,9 \%$ dapat dijelaskan oleh variabel lain yang tidak dibahas dalam penelitian ini, seperti nilai pelanggan, kualitas pelayanan, citra merek, kepercayaan merek, promosi, distribusi, dan variabel lain yang dapat mempengaruhi kepuasan konsumen.

b) Hubungan Harga dengan Kepuasan Konsumen

Hasil koefisien korelasi dan koefisien determinasi dapat dilihat pada tabel berikut:

Tabel 8

Hasil Koefisien Korelasi dan Koefisien Determinasi

\begin{tabular}{|c|c|c|c|c|}
\hline Model & $\mathbf{R}$ & $\begin{array}{c}\mathbf{R} \\
\text { Square }\end{array}$ & $\begin{array}{c}\text { Adjusted } R \\
\text { Square }\end{array}$ & $\begin{array}{c}\text { Std. Error of the } \\
\text { Estimate }\end{array}$ \\
\hline 1 & $\mathbf{. 5 2 1}^{\mathbf{a}}$ & $\mathbf{. 2 7 1}$ & .263 & 4.327 \\
\hline
\end{tabular}

a. Predictors: (Constant), Harga

b. Dependent Variable: Kepuasan Konsumen Sumber: hasil pengolahan data dengan SPSS versi 21 Berdasarkan tabel 8, telah didapat $\mathrm{r}=0,555$ yang artinya terdapat hubungan yang sedang dan positif antara kualitas produk dengan kepuasan konsumen sepeda Polygon Strattos pada PT Insera Sena. Selanjutnya diperoleh koefisien determinasi R square 0,309 artinya tinggi rendahnya kepuasan konsumen sebesar 30,9\% dapat dijelaskan oleh variabel kualitas produk, sedangkan sisanya 69,1\% dapat dijelaskan oleh variabel lain yang tidak dibahas dalam penelitian ini, seperti nilai pelanggan, kualitas pelayanan, citra merek, kepercayaan merek, promosi, distribusi, dan variabel lain yang dapat mempengaruhi loyalitas merek.

c) Hubungan Kualitas Produk dengan Kepuasan Konsumen 
Hasil koefisien korelasi dan koefisien determinasi dapat dilihat pada tabel berikut:

\section{Tabel 9}

Hasil Koefisien Korelasi dan Koefisien Determinasi

\begin{tabular}{|c|c|c|c|c|}
\hline Model & $\mathbf{R}$ & $\begin{array}{c}\mathbf{R} \\
\text { Square }\end{array}$ & $\begin{array}{c}\text { Adjusted } R \\
\text { Square }\end{array}$ & $\begin{array}{c}\text { Std. Error of the } \\
\text { Estimate }\end{array}$ \\
\hline 1 & $\mathbf{. 5 5 5}^{\mathbf{a}}$ & $\mathbf{. 3 0 9}$ & .301 & 4.215 \\
\hline
\end{tabular}

a. Predictors: (Constant), Kualitas Produk

b. Dependent Variable: Kepuasan Konsumen

Sumber: hasil pengolahan data dengan SPSS versi 21

Berdasarkan tabel 9, telah didapat $r=0,555$ yang artinya terdapat hubungan yang sedang dan positif antara kualitas produk dengan kepuasan konsumen sepeda Polygon Strattos pada PT Insera Sena. Selanjutnya diperoleh koefisien determinasi R square 0,309 artinya tinggi rendahnya kepuasan konsumen sebesar 30,9\% dapat dijelaskan oleh variabel kualitas produk, sedangkan sisanya 69,1\% dapat dijelaskan oleh variabel lain yang tidak dibahas dalam penelitian ini, seperti nilai pelanggan, kualitas pelayanan, citra merek, kepercayaan merek, promosi, distribusi, dan variabel lain yang dapat mempengaruhi loyalitas merek.

d) Hubungan Kepuasan Konsumen dengan Loyalitas Merek

Hasil koefisien korelasi dan koefisien determinasi dapat dilihat pada tabel berikut:

Tabel 10

Hasil Koefisien Korelasi dan Koefisien Determinasi

\begin{tabular}{|c|c|c|c|c|}
\hline Model & $\mathbf{R}$ & $\begin{array}{c}\mathbf{R} \\
\text { Square }\end{array}$ & $\begin{array}{c}\text { Adjusted } R \\
\text { Square }\end{array}$ & $\begin{array}{c}\text { Std. Error of the } \\
\text { Estimate }\end{array}$ \\
\hline 1 & $\mathbf{. 5 7 0}^{\mathbf{a}}$ & $\mathbf{. 3 2 5}$ & .317 & 5.826 \\
\hline
\end{tabular}

a. Predictors: (Constant), Kepuasan Konsumen

b. Dependent Variable: Loyalitas Merek

Sumber: hasil pengolahan data dengan SPSS versi 21 Berdasarkan tabel 9, telah didapat $\mathrm{r}=0,570$ yang artinya terdapat hubungan yang sedang dan positif antara kepuasan konsumen dengan loyalitas merek sepeda Polygon Strattos pada PT Insera Sena. Selanjutnya diperoleh koefisien determinasi $\mathrm{R}$ square 0,325 artinya tinggi rendahnya loyalitas merek sebesar $32,5 \%$ dapat dijelaskan oleh variabel kepuasan konsumen, sedangkan sisanya $67,5 \%$ dapat dijelaskan oleh variabel lain yang tidak dibahas dalam penelitian ini, seperti nilai pelanggan, kualitas pelayanan, citra merek, kepercayaan merek, promosi, distribusi, dan variabel lain yang dapat mempengaruhi loyalitas merek.

\section{3) Uji Hipotesis \\ a) Uji Hipotesis 1}

\section{Pengaruh Harga dan Kualitas Produk Terhadap Kepuasan Konsumen Sepeda Polygon Strattos pada PT Insera Sena Secara Simultan}

Uji hipotesis yang pertama menggunakan Uji $\mathrm{F}$ untuk mengetahui apakah variabel bebas (harga dan kualitas produk) berpengaruh terhadap variabel intervening (kepuasan konsumen) secara bersamasama atau simultan. Jika $F_{\text {hitung }}>F_{\text {tabel }}$ atau signifikansi $\leq 0,05$, maka $\mathrm{H}_{0}$ ditolak. Pengujian ini menggunakan program aplikasi SPSS Versi 21 yang dapat dilihat pada tabel berikut ini:

Tabel 11

Hasil Uji Simultan (Uji F)

\begin{tabular}{|l|r|r|r|r|r|}
\hline Model & $\begin{array}{c}\text { Sum of } \\
\text { Squares }\end{array}$ & df & $\begin{array}{c}\text { Mean } \\
\text { Square }\end{array}$ & F & Sig. \\
\hline Regression & 771.024 & 2 & 385.512 & $\mathbf{2 2 . 5 0 2}$ & $\mathbf{. 0 0}^{\mathbf{b}}$ \\
1 Residual & 1490.531 & 87 & 17.133 & & \\
Total & 2261.556 & 89 & & & \\
\hline
\end{tabular}

a. Dependent Variable: Kepuasan Konsumen

b. Predictors: (Constant), Harga, Kualitas Produk Sumber: hasil pengolahan data dengan SPSS versi 21

Berdasarkan tabel 30 di atas diperoleh nilai $F_{\text {hitung }}$ sebesar 22,502 sedangkan $F_{\text {tabel }}(0,05 ; 2$ VS 87 \{90-2-1\}) sebesar 3,10 atau dengan taraf sigifikansi $0,000<\alpha 0,05$, maka $\mathrm{H}_{0}$ ditolak, artinya harga dan kualitas produk berpengaruh positif dan signifikan terhadap kepuasan konsumen sepeda Polygon Strattos pada PT Insera Sena secara simultan.

b) Uji Hipotesis 2

Pengaruh Harga dan Kualitas Produk Terhadap Kepuasan Konsumen Sepeda Polygon Strattos pada PT Insera Sena Secara Parsial

Uji hipotesis yang kedua menggunakan Uji t untuk mengetahui apakah antar variabel bebas (harga dan kualitas produk) dan variabel intervening (kepuasan konsumen) mempunyai hubungan yang signifikan atau tidak. Jika $t_{\text {hitung }}>$ $t_{\text {tabel }}$ atau signifikansi $\leq 0,05$, maka $\mathrm{H}_{0}$ ditolak. Untuk mengetahui $\mathrm{t}_{\text {tabel }}$ digunakan ketentuan $\mathrm{n}-\mathrm{k}-1$ pada level kesalahan 5\% atau 0,05 dengan tingkat keyakinan $95 \%$.

Perhitungan uji t harga terhadap kepuasan konsumen dibantu dengan menggunakan program aplikasi SPSS Versi 21 yang dapat dilihat dari tabel berikut ini:

Tabel 12

Perkiraan Nilai $\mathbf{t}_{\text {hitung }}$ Coefficients $^{a}$

\begin{tabular}{|l|l|l|}
\hline & & \\
Model & $\mathrm{t}$ & Sig. \\
\hline
\end{tabular}




\begin{tabular}{|ll|r|r|}
\hline 1 & (Constant $)$ & 5.484 & .000 \\
& Harga & $\mathbf{2 . 0 6 7}$ & $\mathbf{. 0 4 2}$ \\
\hline
\end{tabular}

a. Dependent Variable: Kepuasan Konsumen

Sumber: hasil pengolahan data dengan SPSS versi 21 Berdasarkan tabel 12 di atas, dapat dilihat nilai $t_{\text {hitung }}$ pada variabel harga $\left(\mathrm{X}_{1}\right)$ sebesar 2,067, sedangkan tabel dengan $\mathrm{df}=\mathrm{n}-\mathrm{k}-1(90-2-1=87)$ sebesar 1,9876 atau dengan taraf signifikan 0,042< a 0,05 , maka $\mathrm{H}_{0}$ ditolak, artinya harga berpengaruh positif dan signifikan terhadap kepuasan konsumen sepeda Polygon Strattos pada PT Insera Sena.

Selanjutnya perhitungan uji $\mathrm{t}$ kualitas produk dibantu dengan menggunakan program aplikasi SPSS Versi 21 yang dapat dilihat dari tabel berikut ini:

Tabel 13

Perkiraan Nilai $\mathbf{t}_{\text {hitung }}$ Coefficients $^{a}$

\begin{tabular}{|ll|r|r|}
\hline \multicolumn{1}{|c|}{ Model } & $\mathrm{t}$ & \multicolumn{1}{c|}{ Sig. } \\
\hline 1 & (Constant) & 5.484 & .000 \\
& Kualitas Produk & $\mathbf{3 . 0 2 7}$ & $\mathbf{. 0 0 3}$ \\
& & & \\
\hline
\end{tabular}

a. Dependent Variable: Kepuasan Konsumen

Sumber: hasil pengolahan data dengan SPSS versi 21 Berdasarkan tabel 13 di atas, dapat dilihat nilai $\mathrm{t}_{\text {hitung }}$ pada variabel kualitas produk $\left(\mathrm{X}_{2}\right)$ sebesar 3,027, sedangkan $\mathrm{t}_{\text {tabel }}$ dengan $\mathrm{df}=\mathrm{n}-\mathrm{k}-1(90-2-1$ $=87$ ) sebesar 1,9876 atau dengan taraf signifikan $0,003<\alpha 0,05$, maka $\mathrm{H}_{0}$ ditolak, artinya kualitas produk berpengaruh positif dan signifikan terhadap kepuasan konsumen sepeda Polygon Strattos pada PT Insera Sena.

\section{c) Uji Hipotesis 3}

\section{Pengaruh Kepuasan Konsumen Terhadap Loyalitas Merek Sepeda Polygon Strattos pada PT Insera Sena}

Adapun uji hipotesis yang ketiga menggunakan Uji t untuk mengetahui apakah antar variabel intervening (kepuasan konsumen) dan variabel terikat (loyalitas merek) mempunyai hubungan yang signifikan atau tidak. Jika $t_{\text {hitung }}>$ $t_{\text {tabel }}$ atau signifikansi $\leq 0,05$, maka $\mathrm{H}_{0}$ ditolak. Untuk mengetahui $t_{\text {tabel }}$ digunakan ketentuan n-k-1 pada level kesalahan $5 \%$ atau 0,05 dengan tingkat keyakinan $95 \%$.

Perhitungan uji $t$ kepuasan konsumen terhadap loyalitas merek dibantu dengan menggunakan program aplikasi SPSS Versi 21 yang dapat dilihat dari tabel berikut ini:

Tabel 14

Perkiraan Nilai $\mathbf{t}_{\text {hitung }}$

Coefficients $^{a}$

\begin{tabular}{|ll|r|r|}
\hline 1 & & & \\
\hline 1 Constant $)$ & 3.488 & .001 \\
Kepuasan & & \\
& Konsumen & $\mathbf{6 . 5 0 2}$ & $\mathbf{. 0 0 0}$ \\
& & & \\
\hline
\end{tabular}

a. Dependent Variable: Loyalitas Merek

Sumber: hasil pengolahan data dengan SPSS versi 21

Berdasarkan tabel 14 di atas, dapat dilihat nilai $t_{\text {hitung }}$ pada variabel kepuasan konsumen $(\mathrm{Z})$ sebesar 6,502, sedangkan $\mathrm{t}_{\text {tabel }}$ dengan $\mathrm{df}=\mathrm{n}-\mathrm{k}-1$ $(90-1-1=88)$ sebesar 1,9873 atau dengan taraf signifikan $0,000<\alpha 0,05$, maka $\mathrm{H}_{0}$ ditolak, artinya kepuasan konsumen berpengaruh positif dan signifikan terhadap loyalitas merek sepeda Polygon Strattos pada PT Insera Sena.

\section{Evaluasi}

\section{Harga Sepeda Polygon Strattos Pada PT}

\section{Insera Sena}

Berdasarkan dimensi yang digunakan dalam penelitian ini, hasil yang diperoleh dapat dijelaskan bahwa harga sepeda Polygon Strattos pada PT Insera Sena di Komunitas Polygon Strattos User Indonesia dapat dikategorikan cukup baik, hal tersebut dibuktikan berdasarkan hasil kuesioner yang diperoleh nilai rata-rata 3,33 dengan kategori jawaban cukup baik.

Pada dimensi harga tersebut, beberapa indikator yang masih di bawah nilai rata-rata, yaitu pada indikator harga Polygon Strattos terjangkau sesuai dengan daya beli konsumen dengan nilai ratarata 3,27. Cara untuk mengatasi kekurangan ini, PT Insera Sena sebaiknya memberikan informasi lagi secara jelas kepada konsumen mengenai nilai (value) yang diberikan produk sepeda Polygon Strattos lebih tinggi jika dibandingkan dengan harga yang ditawarkan oleh PT Insera Sena. Bahwa sepeda Polygon Strattos cukup murah bahkan sudah di bawah harga pasaran merek sepeda lain, seperti Trek, Giant, Specialized, Cervelo, dan merek sepeda global lainnya dengan kelas dan kualitas yang sama.

Selanjutnya, pada indikator harga Polygon Strattos kompetitif dibanding pesaing dengan nilai rata-rata 3,21. Mengatasi hal tersebut, PT Insera Sena sebaiknya melakukan kegiatan promosi untuk menciptakan persepsi produk sepeda Polygon Strattos memiliki harga yang relatif lebih kompetitif dengan nilai yang ditawarkan lebih banyak dibandingkan pesaing, seperti menggunakan material frameset berkualitas, produk asli Indonesia, didesain oleh pakar dan ahli sepeda, dan melibatkan atlet profesional dalam produksi sepedanya. Kemudian pada dimensi potongan harga, yaitu pada indikator pemberian potongan harga pada konsumen yang membeli Polygon Strattos dalam jumlah banyak dengan nilai rata-rata 2,91. Cara untuk mengatasi hal ini adalah selain daripada memberikan potongan harga kepada konsumen korporasi, PT Insera Sena sebaiknya perlu memberikan potongan harga kepada

\begin{tabular}{|l|l|l|}
\hline Model & $\mathrm{t}$ & Sig. \\
\hline
\end{tabular}


konsumen ritel yang membeli sepeda dengan jumlah lebih dari 1 (satu).

Untuk kekurangan pada dimensi potongan harga, yaitu indikator pemberian potongan harga Polygon Strattos pada hari-hari besar berada pada nilai rata-rata 3,01. Cara yang dilakukan untuk mengatasi hal ini adalah PT Insera Sena juga sebaiknya mempertimbangkan pemberian diskon pada hari-hari besar selain dari tahun baru, yaitu seperti HUT RI 17 Agustus, Hari raya Idul Fitri, Natal maupun hari besar lainnya. Selanjutnya untuk dimensi cara pembayaran, yaitu pada indikator Polygon Strattos dapat dibayar secara kredit atau cicilan pada berada pada tingkat nilai rata-rata 3,18. Cara untuk mengatasi hal ini adalah sebaiknya PT Insera Sena memberikan fasilitas pembelian sepeda Polygon Strattos secara kredit atau cicilan pada semua cabang outlet Rodalink.

\section{Kualitas Produk Sepeda Polygon Strattos \\ Pada PT Insera Sena}

Kualitas produk adalah suatu hasil produksi berupa barang yang diberikan kepada konsumen dimana produk tersebut dapat memenuhi keinginan, kebutuhan, dan kepuasan konsumen. Berdasarkan dimensi kualitas produk yang digunakan untuk mengukur kepuasan konsumen sepeda Polygon Strattos milik PT Insera Sena dapat dikategorikan cukup baik, yang dilihat dari segi kinerja (performance), keandalan (reliability), fitur (feature), keawetan (durability), kesesuaian (conformance), dan estetika (aesthetics). Oleh sebab itu, kualitas produk yang baik sangat diperlukan dalam perusahaan agar konsumen merasa puas atas produk yang mereka terima, sehingga pada akhirnya akan meningkatkan loyalitas merek.

Walaupun demikian, dalam dimensi kualitas produk sepeda Polygon Strattos pada PT Insera Sena masih terdapat beberapa kekurangan. Hal tersebut disebabkan, dalam menerapkan kualitas produk dari responden masih terdapat nilai di bawah rata-rata total jawaban responden, yaitu 3,16. Seperti pada dimensi kinerja (performance) dalam hal berat sepeda Polygon Strattos mendukung kinerja sepeda yang cepat hanya memiliki nilai rata-rata 2,72. Maka untuk mengatasi hal ini, PT Insera Sena sebaiknya perlu mengurangi berat atau bobot sepeda Polygon Strattos dengan menggunakan material aluminium yang lebih ringan untuk rangka sepedanya.

Pada dimensi keandalan (reliability) dalam hal Polygon Strattos menggunakan komponen berkualitas mendukung keandalan sepeda hanya memiliki nilai rata-rata 3,11. Maka untuk mengatasi hal tersebut, PT Insera Sena sebaiknya perlu meningkatkan kualitas dari komponen sepeda Polygon Strattos produksinya, dengan cara memfasilitasi sistem custom untuk setiap konsumen. Hal tersebut dapat membuat konsumen memilih sendiri komponen yang akan digunakan di sepeda Polygon Strattosnya.

Untuk dimensi fitur (feature) dalam hal konsumen mendapat fitur test ride Polygon Strattos di outlet Rodalink memiliki tingkat nilai rata-rata
2,86. Maka untuk mengatasi hal tersebut, PT Insera Sena sebaiknya perlu meningkatkan pelayanan dalam pembelian sepeda Polygon Strattos dengan menambahkan fitur test ride sebagai standar untuk seluruh outlet Rodalink. Lalu dalam hal konsumen mendapat fitur bike fitting sehingga sepeda yang telah dibeli nyaman dipakai memiliki tingkat nilai rata-rata 2,77. Maka untuk mengatasi hal tersebut, PT Insera Sena sebaiknya perlu meningkatkan pelayanan dalam pembelian sepeda Polygon Strattos dengan menambahkan fitur bike fitting sebagai standar untuk seluruh outlet Rodalink.

Pada dimensi keawetan (durability) dalam hal harga jual kembali Polygon Strattos memiliki tingkat nilai sedikit di bawah rata-rata, yaitu 3,13. Untuk mengatasi hal tersebut, PT Insera Sena sebaiknya perlu menambah fasilitas seperti tukar tambah pembelian sepeda Polygon Strattos dengan tingkat harga yang wajar. Sehingga konsumen dapat langsung membeli sepeda yang baru dengan menukar sepeda Polygon Strattos lama miliknya dan menambah selisih harga dengan sepeda yang baru tersebut.

Selanjutnya dalam dimensi kesesuaian (conformance) dalam hal Polygon Strattos diproduksi dengan standar internasional berada pada nilai rata-rata 2,92. Dalam hal ini, PT Insera Sena sebaiknya perlu meningkatkan lagi standar produksi sepeda Polygon Strattos dengan memenuhi standar dari Persatuan Balap Sepeda Internasional atau Union Cycliste Internationale (UCI), agar konsumen dapat merasa lebih puas dalam menggunakan produk ini. Selain itu, untuk dimensi estetika (aesthetics) dalam hal Polygon Srattos mempunyai desain terbaru sehingga mendukung estetika hanya berada pada nilai rata-rata 2,93. Untuk mengatasi hal tersebut, PT Insera Sena sebaiknya perlu memiliki desain terbaru yang berbeda dari produsen lain dengan cara menerima saran dari konsumennya.

Untuk hal Polygon Strattos mempunyai decal (stiker) yang kualitas finishing-nya rapi berada pada nilai rata-rata 3,14. Dalam hal ini, PT Insera Sena sebaiknya perlu untuk lebih meningkatkan pengawasan quality control agar sepeda yang kualitas stikernya kurang bagus tidak sampai kepada konsumen. Sementara itu, dalam hal Polygon Strattos mempunyai pilihan warna beragam sehingga konsumen dapat memilih hanya memiliki nilai ratarata 2,58 dengan kategori tidak baik. Cara mengatasi hal tersebut adalah PT Insera Sena sebaiknya memproduksi setiap seri Polygon Strattos dengan beberapa pilihan warna yang menarik, sehingga konsumen bisa memilih warna sepeda yang sesuai dengan seleranya.

\section{Kepuasan Konsumen Sepeda Polygon Strattos PT Insera Sena}

Kepuasan konsumen adalah perasaan yang ditunjukan oleh konsumen dengan membandingkan kinerja atau hasil yang diharapkan. Jika kinerja produk lebih rendah dari harapan konsumen, maka konsumen akan memiliki persepsi negatif atau kecewa, sedangkan bila kinerja sesuai dengan 
harapan, maka konsumen akan memiliki persepsi positif atau puas. Kepuasan konsumen dapat diukur dari beberapa dimensi, yaitu kenyamanan prosedur dan dukungan konsumen. Oleh karena itu, kepuasan konsumen sangat penting sebab jika konsumen memiliki persepsi positif atau puas maka konsumen tersebut akan selalu menggunakan produk sepeda yang ditawarkan oleh PT Insera Sena.

Namun demikian kepuasan konsumen sepeda Polygon Strattos pada PT Insera Sena masih terdapat nilai dibawah rata-rata jawaban responden, yaitu 3,18 . Beberapa dimensi seperti harga dalam hal tingkat kepuasan konsumen atas harga Polygon Strattos yang ditawarkan oleh Rodalink yang hanya memiliki nilai rata-rata 3,02. Dalam hal tingkat kepuasan konsumen atas harga sepeda Polygon Strattos yang ditawarkan PT Insera Sena sebaiknya perlu menyampaikan kepada konsumen mengenai nilai-nilai yang ditawarkan oleh produk ini sehingga persepsi nilai sepeda Polygon Strattos lebih tinggi dibandingkan harga yang ditawarkan. Selain itu, dalam hal tingkat kepuasan konsumen terhadap variasi harga Polygon Strattos yang ditawarkan oleh hanya memiliki nilai rata-rata jawaban 2,94. Hal ini dapat diatasi dengan cara PT Insera Sena sebaiknya memberikan sejumlah keuntungan berupa hadiah langsung kepada konsumen yang membeli sepeda Polygon Strattos.

Selanjutnya, untuk dimensi kenyamanan prosedur seperti tingkat kepuasan konsumen atas kenyamanan klaim garansi Polygon Strattos hanya memiliki tingkat nilai rata-rata 3,14. Untuk mengatasi hal tersebut, PT Insera sebaiknya meningkatkan lagi kecepatan respon pegawai dalam melayani konsumen yang melakukan klaim garansi, seperti konsumen yang belum pernah tahu tata cara klaim garansi yang benar untuk diedukasi dan diberi informasi mengenai detail klaim sepeda Polygon Strattos miliknya.

Untuk dimensi dukungan konsumen seperti tingkat kepuasan konsumen atas informasi Polygon Strattos di website Rodalink hanya memiliki tingkat nilai rata-rata 2,88. Dalam hal ini, PT Insera Sena sebaiknya perlu meningkatkan dukungan konsumen tentang informasi sepeda Polygon Strattos di website Rodalink milik PT Insera Sena. Sehingga konsumen lebih mendapatkan informasi detail mengenai sepeda Polygon Strattos dan tertarik untuk membelinya.

\section{Loyalitas Merek Sepeda Polygon Strattos PT Insera Sena}

Loyalitas merek adalah ukuran yang lebih dapat diandalkan untuk memprediksi pertumbuhan penjualan dan keuangan. Berbeda dari kepuasan, yang merupakan sikap, loyalitas merek dapat didefinisikan berdasarkan perilaku membeli. Konsumen yang loyal adalah orang yang melakukan pembelian berulang secara teratur, membeli antarlini produk dan jasa, mereferensikan kepada orang lain, dan menunjukkan kekebalan terhadap merek dari pesaing. Oleh karena itu, loyalitas merek menjadi bagian penting dalam strategi pemasaran perusahaan untuk mempertahankan mereknya dari pesaing.
Berdasarkan dimensi loyalitas merek yang digunakan untuk mengukur loyalitas merek sepeda Polygon Strattos milik PT Insera Sena dapat dikategorikan cukup baik dengan nilai rata-rata 3,13. Berdasarkan hasil penelitian ini, masih terdapat beberapa kekurangan. Hal tersebut disebabkan, dalam menerapkan loyalitas merek masih terdapat nilai di bawah rata-rata total jawaban responden, yaitu 3,13. Pada dimensi switcher dalam hal tidak akan berpindah merek dari Polygon Strattos karena faktor harga berada pada nilai rata-rata 2,96. Untuk mengatasi hal ini, PT Insera Sena sebaiknya perlu untuk menambahkan nilai sepeda Polygon Strattos seperti nilai tentang lingkungan hidup, nilai tentang produk asli Indonesia, dan sebagainya agar konsumen mendapatkan persepsi nilai yang lebih tinggi dibandingkan dengan biaya yang dikeluarkan untuk memperoleh produk ini.

Pada indikator tidak akan berpindah merek dari Polygon Strattos karena faktor kualitas produk berada pada nilai rata-rata 2,92 . Untuk mengatasi hal tersebut, PT Insera Sena sebaiknya perlu untuk meningkatkan kepercayaan konsumen terhadap kualitas produknya melalui quality control yang ketat sehingga meminimalisir cacat pada sepeda yang telah dipasarkan. Selanjutnya dalam hal tidak akan berpindah merek dari Polygon Strattos karena faktor kepuasan berada pada nilai rata-rata 2,92. Untuk mengatasi hal ini, PT Insera Sena perlu mengadakan berbagai kegiatan (event) yang berhubungan dengan sepeda dan komunitasnya, seperti funbike, car free day, dan sebagainya agar setiap konsumen yang mengikuti kegiatan tersebut mendapatkan manfaat tambahan berupa pertemanan dengan kelompok yang menggunakan produk yang sama, menambah wawasan tentang persepedaan, dan sebagainya yang akan meningkatkan kepuasan konsumen.

Pada dimensi habitual buyer dalam hal membeli Polygon Strattos hanya karena kebiasaan pribadi berada pada nilai rata-rata 3,04. Untuk mengatasi hal ini, PT Insera Sena sebaiknya perlu mempersonalisasikan pemasaran produknya agar perusahaan dapat menciptakan ikatan yang kuat bagi setiap konsumennya. Sehingga hal ini dapat meningkatkan preferensi pribadi konsumen terhadap produk sepeda Polygon Strattos pada masa yang akan datang. Lalu dalam hal membeli Polygon Strattos hanya karena kebiasaan komunitas berada pada nilai rata-rata 3,12. Dalam hal ini, PT Insera Sena sebaiknya perlu maksimal dalam memanfaatkan komunitas sepeda sebagai wadah untuk menampung saran, kritik, dan masukan yang berguna bagi pengembangan produk. Selanjutnya dalam hal membeli Polygon Strattos hanya karena kebiasaan lingkungan berada pada nilai rata-rata 3,06. Dalam hal ini PT Insera Sena sebaiknya perlu untuk mempertimbangkan pemasaran melalui komunitas dan lingkungan perkotaan yang masyarakatnya mulai sadarnya akan pentingnya kegiatan bersepeda.

Sementara itu, pada dimensi satisfied buyer dalam hal menemukan kepuasan dalam 
menggunakan Polygon Strattos karena faktor merek berada pada nilai rata-rata 3,03. Dalam hal ini PT Insera Sena sebaiknya perlu untuk semakin meningkatkan nilai merek dari sepeda Polygon Strattos, agar konsumen merasa puas dalam menggunakan merek sepeda ini. Kemudian pada dimensi liking the brand dalam hal menyukai merek Polygon Strattos karena kualitas produk tinggi berada pada nilai rata-rata 3,06. Dalam hal ini PT Insera Sena sebaiknya perlu meningkatkan kualitas produk sepeda Polygon Strattos melalui penggunaan standar dari Persatuan Balap Sepeda Internasional atau Union Cycliste Internationale (UCI).

Selanjutnya dalam hal menyukai merek Polygon Strattos karena produk memberi kepuasan paling tinggi berada pada nilai rata-rata 2,92. Dalam hal ini, PT Insera Sena sebaiknya perlu untuk memperhatikan aspek kepuasan konsumennya melalui ikatan kustomisasi, yaitu ikatan yang dibangun ketika penyedia jasa berhasil menyediakan layanan yang disesuaikan kepada konsumennya. Untuk dimensi commited buyer dalam hal tetap memilih merek Polygon Strattos untuk dibeli dikemudian hari berada pada nilai rata-rata 2,96. Untuk mengatasi hal tersebut, PT Insera Sena sebaiknya perlu untuk mengembangkan program loyalitas merek kepada konsumennya dalam hal melibatkan konsumennya dalam hal kegiatan sosial yang bermanfaat bagi masyarakat.

\section{KESIMPULAN DAN SARAN}

\section{Kesimpulan}

a. Hasil analisis deskriptif kualitatif mengenai harga $\left(\mathrm{X}_{1}\right)$ sepeda Polygon Strattos memiliki nilai rata-rata jawaban 3,33 dengan kategori jawaban cukup baik. Indikator nilai tertinggi berada pada dimensi cara pembayaran, yaitu indikator Polygon Strattos dapat dibayar secara langsung pada Rodalink dengan nilai rata-rata 3,88 . Sedangkan nilai rata-rata terendah berada pada dimensi potongan harga, yaitu indikator pemberian potongan harga pada konsumen yang membeli Polygon Strattos dalam jumlah banyak yang hanya memiliki nilai rata-rata 2,91 .

b. Hasil analisis deskriptif kualitatif mengenai kualitas produk $\left(\mathrm{X}_{2}\right)$ sepeda Polygon Strattos pada PT Insera Sena berada pada nilai rata-rata 3,16 dengan kategori jawaban cukup baik. Nilai rata-rata tertinggi berada pada dimensi kesesuaian (conformance), yaitu indikator Polygon Strattos diproduksi dengan Standar Nasional Indonesia (SNI) yang berada pada nilai rata-rata 3,86 . Sedangkan nilai rata-rata terendah berada pada dimensi estetika (aesthetics), yaitu indikator Polygon Strattos mempunyai pilihan warna beragam sehingga konsumen dapat memilih yang hanya memiliki nilai rata-rata 2,58 .

c. Hasil analisis deskriptif kualitatif mengenai kepuasan konsumen (Z) sepeda Polygon Strattos pada PT Insera Sena berada pada nilai rata-rata 3,18 dengan kategori jawaban cukup puas. Nilai rata-rata tertinggi berada pada dimensi kenyamanan prosedur, yaitu indikator tingkat kepuasan dalam membeli Polygon Strattos pada website Rodalink yang memiliki nilai rata-rata 3,41 . Sedangkan nilai rata-rata terendah terdapat pada dimensi dukungan konsumen, yaitu indikator tingkat kepuasan atas dukungan konsumen melalui media sosial Polygon Bikes Indonesia dengan nilai rata-rata 2,88 .

d. Hasil analisis deskriptif kualitatif mengenai loyalitas merek (Y) sepeda Polygon Strattos pada PT Insera Sena berada pada nilai rata-rata 3,13 dengan kategori jawaban cukup baik. Nilai rata-rata tertinggi berada pada dimensi satisfied buyer, yaitu indikator menemukan kepuasan dalam menggunakan Polygon Strattos karena faktor kualitas yang memiliki nilai rata-rata 3,53. Namun terdapat beberapa indikator dibawah nilai rata-rata dengan nilai 2,92, seperti tidak akan berpindah merek karena faktor kualitas produk, dan tidak akan berpindah merek karena faktor kepuasan, serta menyukai merek Polygon Strattos karena produk memberi kepuasan paling tinggi.

e. Terdapat pengaruh harga $\left(\mathrm{X}_{1}\right)$ dan kualitas produk $\left(\mathrm{X}_{2}\right)$ terhadap kepuasan konsumen $(\mathrm{Z})$ sepeda Polygon Strattos yang dibuktikan dengan $\hat{\mathrm{Y}}_{(\mathrm{z})}=17,394+0,292 \mathrm{X}_{1}+0,212 \mathrm{X}_{2}$, dan terdapat pengaruh kepuasan konsumen ( $\mathrm{Z}$ ) terhadap loyalitas merek (Y) yang dibuktikan dengan $\hat{Y}=16,474+0,797 \mathrm{X}_{(\mathrm{z})}$.

f. Terdapat hubungan yang sedang dan positif antara harga $\left(\mathrm{X}_{1}\right)$ dan kualitas produk $\left(\mathrm{X}_{2}\right)$ dengan kepuasan konsumen (Z) yang dibuktikan dengan nilai $\mathrm{r}=0,584$ dengan koefisien determinasi sebesar 34,1\%. Serta terdapat hubungan yang sedang dan positif antara kepuasan konsumen ( $\mathrm{Z}$ ) dengan loyalitas merek (Y) yang dibuktikan dengan nilai $\mathrm{r}=$ 0,570 dengan koefisien determinasi sebesar $32,5 \%$.

g. Hasil pengujian hipotesis 1 diperoleh nilai Fhitung sebesar 22,502 sedangkan Ftabel $(0,05 ; 2$ VS 87) sebesar 3,10 atau dengan taraf sigifikansi 0,000 $<\alpha 0,005$, maka $\mathrm{H}_{0}$ ditolak, artinya harga dan kualitas produk berpengaruh positif dan signifikan terhadap kepuasan konsumen sepeda Polygon Strattos pada PT Insera Sena.

h. Hasil pengujian hipotesis 2 diperoleh nilai $t_{\text {hitung }}$ pada variabel harga $\left(\mathrm{X}_{1}\right)$ sebesar 2,067, sedangkan $\mathrm{t}_{\text {tabel }}$ dengan $\mathrm{df}=\mathrm{n}-\mathrm{k}-1(90-2-1$ $=87$ ) sebesar 1,9876 atau dengan taraf signifikan $0,042<\alpha \quad 0,05$, maka $\mathrm{H}_{0}$ ditolak, artinya harga berpengaruh positif dan signifikan terhadap kepuasan konsumen sepeda Polygon Strattos pada PT Insera Sena. Kemudian nilai $t_{\text {hitung }}$ pada variabel kualitas produk $\left(\mathrm{X}_{2}\right)$ sebesar 3,027, sedangkan $\mathrm{t}_{\text {tabel }}$ dengan $\mathrm{df}=\mathrm{n}-\mathrm{k}-1(90$ $2-1=87$ ) sebesar 1,9876 atau dengan taraf signifikan $0,003<\alpha \quad 0,05$, maka $\mathrm{H}_{0}$ ditolak, artinya kualitas produk berpengaruh positif dan 
signifikan terhadap kepuasan konsumen sepeda Polygon Strattos pada PT Insera Sena.

i. Hasil pengujian hipotesis 3 diperoleh nilai $t_{\text {hitung }}$ pada variabel kepuasan konsumen $(\mathrm{Z})$ sebesar 6,502, sedangkan $\mathrm{t}_{\text {tabel }}$ dengan $\mathrm{df}=\mathrm{n}-\mathrm{k}-1(90$ $1-1=88$ ) sebesar 1,9873 atau dengan taraf signifikan $0,000<\alpha 0,05$, maka $\mathrm{H}_{0}$ ditolak, artinya kepuasan konsumen berpengaruh positif dan signifikan terhadap loyalitas merek sepeda Polygon Strattos pada PT Insera Sena.

\section{Saran}

a. PT Insera Sena sebaiknya menetapkan harga sepeda Polygon Strattos dengan mempertimbangkan pemberian potongan harga pada konsumen yang membeli Polygon Strattos dalam jumlah banyak, dan pada hari besar lain selain pada saat tahun baru. Hal ini dapat meningkatkan minat konsumen untuk menggunakan produk sepeda Polygon Strattos.

b. PT Insera Sena sebaiknya mempertimbangkan sepeda Polygon Strattos diproduksi dengan berbagai pilihan warna menarik pada setiap serinya, sehingga dapat memberikan banyak alternatif pilihan warna bagi konsumen yang membeli sepeda Polygon Strattos.

c. PT Insera Sena sebaiknya memperbaiki kualitas media sosial Polygon Bikes Indonesia agar lebih interaktif dalam berkomunikasi terhadap tanggapan dari pengguna media sosial, sehingga konsumen dapat lebih cepat memperoleh tanggapan dan solusi atas permasalahan yang dihadapi.

d. PT Insera Sena sebaiknya perlu menetapkan kualitas produk dan pelayanan dengan unggul melebihi pesaingnya agar konsumen tidak berpindah merek dari Polygon Strattos karena faktor kualitas produk maupun faktor kepuasan.

e. Sehubungan dengan keterbatasan-keterbatasan yang ada pada penulis, penelitian ini masih terdapat kelemahan dan belum dapat mengungkapkan seluruh variabel yang dapat mempengaruhi kepuasan konsumen dan loyalitas merek sepeda Polygon Strattos pada PT Insera Sena. Sebagai bahan masukan untuk penelitian selanjutnya, perlu memperbanyak variabel penelitian seperti nilai pelanggan, kualitas pelayanan, citra merek, kepercayaan merek, promosi, distribusi, dan variabel lain yang dapat mempengaruhi kepuasan konsumen dan loyalitas merek.

\section{E. DAFTAR PUSTAKA}

Buttle, Francis. 2007. Manajemen Hubungan Pelanggan: Concepts and Tools. Edisi I. Jakarta: Bayumedia Publishing.

Doyle, Charles. 2013. Kamus Pemasaran. Cetakan Pertama. Jakarta: Indeks.

Durianto, et. al. 2004. Brand Equity Ten: Strategi Memimpin Pasar. Jakarta: PT Gramedia Pustaka Utama.

Ghozali, Imam, 2005. Aplikasi Analisis Multivariate dengan Program SPSS. Edisi
Ketiga. Semarang: Badan Penerbit Universitas Diponegoro.

2016. Aplikasi Analisis Multivariate dengan Program IBM SPSS 23. Edisi 8. Semarang: Badan Penerbit Universitas Diponegoro.

Griffin, Jill. 2003. Customer Loyalty: Menumbuhkan dan Mempertahankan Kesetiaan Pelanggan. Jakarta: Erlangga.

Griffin, Ricky W dan Ronald J. Ebert. 2006. Bisnis. Edisi Ketujuh, Jilid 2. Jakarta: PT Indeks.

Hart, Norman A dan John Stapleton. 2005. Kamus Marketing. Cetakan Kedua. Jakarta: PT Bumi Aksara.

Hasan, Ali. 2013. Marketing Dan Kasus-Kasus Pilihan. Cetakan Kedua. Jakarta: Center for Academic Publishing Service.

Kotler, Philip dan Gary Armstrong. 2008. PrinsipPrinsip Pemasaran. Edisi XII, Jilid 1. Jakarta: Erlangga.

Kotler, Philip dan Kevin Lane Keller. 2007. Manajemen Pemasaran. Edisi XII, Jilid 1. Jakarta: PT Indeks.

Kotler, Philip dan Kevin Lane Keller. 2009. Manajemen Pemasaran. Edisi XIII, Jilid 1. Jakarta: Erlangga.

Mowen, John C., dan Michael Minor. 2002. Perilaku Konsumen. Edisi Kelima, Jilid 2. Jakarta: Erlangga.

Simbolon, Hotman. 2009. Statistika. Edisi Pertama. Yogyakarta: Graha Ilmu.

Sugiyono. 2013. Metode Penelitian Manajemen. Bandung: Alfabeta.

Tjiptono, Fandy. 2015. Strategi Pemasaran. Edisi 4. Yogyakarta: Andi. 